\title{
Berlinale 2008
}

\author{
By Ron Holloway \\ Spring 2008 Issue of KINEMA
}

\section{$58^{\text {th }}$ BERLINALE 2008}

\section{Box Office Bonanza}

Will it ever end? During his seven years as Berlinale director, Dieter Kosslick's festival tenure is annually boosted by success at the box office. Following the close of the 58th Berlin International Film Festival (7-17 February 2008), bonanza statistics were promptly released to the press. The 58th Berlinale recorded an overall audience of 430,000, of which some 230,000 purchased tickets, thus exceeding last year's record by more than 6,000. The number of visiting film professionals (exhibitors, sales agents, industry representatives) increased to 20,000 from 125 countries, topping last year's total of 19,155. The number of accredited journalists rose to 4,105 . The sum of public screenings also rose to 1,256 , compared with 934 screenings in 2007. Only the number of films participating in this year's official programs dipped in comparison to last year - down from 396 to 383 - but even this adjustment apparently made some Berlinale entries all the more attractive.

The buzz at the Berlinale? Of particular interest were the "EFM Industry Debates" held in the Marriott Hotel for three days in the middle of the festival. A hundred participants registered for the panel discussions on the challenges and opportunities of "Digital Film Distribution" in the not too distant future. Another press headliner was a calculation on the "monetary worth" of this year's Berlinale, reckoned at circa $€ 17.2 \mathrm{~m}$, or around US\$26m. The sum includes the input by the German government (country, state, city), estimated at $€ 6.2 \mathrm{~m}$, or approximately US\$ $9.3 \mathrm{~m}$. As for coin flowing back into Berlin coffers (hotels, restaurants, services), this was calculated at circa $€ 350 \mathrm{~m}$, or around US\$525m. In this regard, it should be added that the city hotel managers are particularly pleased that the Berlinale is scheduled annually in February, a month generally reckoned as the slowest on the hotelier calendar. Add up these statistics and estimates, then the Berlinale can be deemed a cultural and entertainment event of the first rank.

\section{European Film Market Bursts Its Seams}

Popularity has its price. A few years back, some critics felt that the massive two-story Gropius Bau was a mite too spacious for the European Film Market (EFM). But the opposite turned out to be true. Last year, market director Beki Probst had to expand her facilities - and fortunately found additional space in the "EFM Exhibitor Offices" on Potsdamer Platz. This year, however, the EFM burst its seams again. Altogether, 430 companies from 51 countries booked stands in the adjacent facilities, in addition to 60 companies based in local hotels. Further, 1,073 buyers from 54 countries were registered, an increase of $3 \%$ over last year. Moreover, market screenings totalled nearly 1,100, mostly in the venues at the Cinemaxx and Cinestar multiplexes near the Potsdamer Platz.

Ask film marketeers how they evaluate the EFM, and they will cite its February dates as a key reason for its growing success. Since the American Film Market (AFM) in Los Angeles takes place in November, and the Village International at Cannes doesn't open its doors until the following May, the EFM at the Berlinale benefits from its position as an attractive in-between rendezvous. Indeed, there are many film professionals who would even go so far as to rate some EFM screenings a notch higher than the entries in the Berlinale Competition. But now the EFM is faced with a dilemma prompted by its growing pains. "It appears that the Exhibitor Offices may not available in 2009," said Beki Probst in an interview. "The owners would like to rent the space out for a longer period of time." Negotiations are currently underway to resolve the dilemma.

\section{Rolling Stones and Rock Idols}

For many, the presence of the Rolling Stones at the opening night gala sent the tone for the entire festival. Scalpers could have asked a small fortune for a ticket to the Berlinale premiere of Martin Scorsese's Shine a Light (USA), a documentary on the band's two-night performances at the Beacon Theatre in New York in the autumn of 2006. Dieter Kosslick, himself a one-time guitarist in a rock band, worked tirelessly for months to bring the Rolling Stones in person to Berlin. Once Scorsese and the Stones had confirmed their presence, 
he then had to accommodate the city elite and festival VIPs with tickets to screenings in the Berlinale Palast (1600 seats) and the Zoo Palast (1000 seats), in addition to backup shows for hungry rock fans. As for the echo in the press, some cited Shine a Light as a media event par excellence in the annals of the Berlinale.

Other rock attractions powered the Panorama. Madonna's Filth and Wisdom (UK), her directorial debut reportedly inspired by a liking for Godard and Pasolini films, proved to be little more than an amusing curi osity. Three quirky London flat-dwellers - Ukrainian "gypsy punk singer" Eugene Hutz (whose Gogol Bordello Band blares on the soundtrack), joined by oddball actresses Holly Weston and Juliette McClure offer a glimpse into the London underground performance scene. "I had to learn how to make a film," mused Madonna in an interview, "so I paid for it myself!" Steven Seberg's documentary, Patti Smith: Dream of Life (USA), fared better. Eleven years in the making, this portrait of the legendary "Punk Poet Laureate" (singer, songwriter, poet, painter, journalist) was hiked at the press conference when she pulled out her guitar for a rendition of "Because the Night" (co-written in 1978 with Bruce Springsteen). Last, but not least, there was the warmly received Neil Young documentary, CSNY: Déjà Vu (USA), directed by Bernard Shakey (a pseudonym for Neil Young). The film links the current anti-Iraq-War protests by the folk/rock CSNY band - read: (David) Crosby, (Stephen) Stills, (Graham) Nash, (Neil) Young - with film and TV footage in their previous "Déjà" album recorded at the height of the anti-Vietnam movement. CSNY: Déjà Vu came directly from the Sundance festival for its Berlinale Special screening.

\section{Living Room Festival}

"Dieter runs the Berlinale like the festival is in his living room," mused Paul Thomas Anderson, whose Magnolia (USA) had been awarded the Golden Bear at the 2000 Berlinale. This year, Anderson returned to Berlin with There Will Be Blood (USA), a free adaptation of Upton Sinclair's best-seller Oil (published in 1927), his socialist novel exposing the soft underbelly of the oil industry in southern California during the corrupt Harding administration. From the outset, There Will Be Blood was a critical favourite to win the Golden Bear, the same went for Daniel Day Lewis to win the Silver Bear as Best Actor. In the end, however, the International Jury decided otherwise: Paul Thomas Anderson was awarded a Silver Bear for Best Director, while the Silver Bear for Best Artistic Contribution was awarded to film composer Jonny Greenwood.

With the Oscars scheduled but a week after the close of the Berlinale - on February 24 - at which There Will Be Blood had already been nominated in six categories, perhaps the International Jury cannot be slighted for opting for what is referred to in the trade papers as "festival fair play." After all, as confirmed in critics voting lists, it can be argued that There Will Be Blood was the outstanding hit of the 2008 Berlinale. Yet critics raised their collective eyebrows when it was announced that two women jury members, French cult actress Sandrine Bonnaire and Danish dogma director Susanne Bier, had cancelled their jury presence at the last minute. Thus, with seven jury members on hand - instead of the usual nine - a couple blown fuses had darkened Dieter's living room. A breakdown like this happens seldom at an A-Category Festival.

\section{Costa-Gavras Bears}

Were critical voices justified in tracing the decision by the international jury to award the Golden Bear to José Padilha's Tropa de elite (The Elite Squad, Brazil) to the presence of Constantin Costa-Gavras on the jury as its president? Probably not, even though the politically engaged Costa-Gavras had previously been awarded the Golden Palm at the 1982 Cannes festival for Missing and the Golden Bear at the 1990 Berlinale for The Music Box. Besides, The Elite Squad was already a Brazilian blockbuster before the film even arrived in Berlin. Padilha picks up where he left off in his highly charged fiction-documentary Bus 174 (2002), the true story about a bungled attempt by a SWAT police team to rescue hostages on a public bus that was reported in detail on local television. Further, The Elite Squad, based on a best-seller and shot in the vein of Fernando Meirelles's acclaimed City of God (2002), is set in the past. Back in 1997, when the Pope planned to visit Brazil, the news of his stay triggered a drive by a corrupt Special Police Operation Battalion (BOPE) to rid the Rio slums of drug barons, cost what it may. Brutality, violence, torture, and executions became the order of the day. And that drug war, according to Padilha, has continued unabated up to the present.

Errol Morris's Standard Operating Procedure (USA), awarded the festival's runner-up Silver Bear, Special Jury Prize, certainly deserved jury attention as the first documentary to ever appear in the Berlinale com- 
petition. Also, a lot can be said for Morris picking up where his Oscar-winning The Fog of War (2003) had left off. Remember those "eleven lessons" learned by Defence Secretary Robert S. McNamara about the mistakes that he (along with the administrations under Presidents Kennedy and Johnson) had made during the Vietnam War? Moreover, since Morris had spent two years researching Standard Operating Procedure, he can be praised for obtaining on-camera interviews with five of the seven indicted MPs at the notorious Abu Ghraib prison. But what really makes the documentary exceptional is that three of those interviewed are women - among them former Brigadier General Janis Karpinski, who feels she had been made the scapegoat by higher-ups in the military command who thus escaped without a blemish on their records. Given that a festival audience is generally known for its patience in watching long-winded talking-head documentaries, the real test will come in April, when the 116-minute Standard Operating Procedure is scheduled to reach American audiences. Seldom has a documentary weighed in such lucid terms the pros and cons of physical and mental torture against interrogation regulations as stipulated in the military rule-book. The moral rationale of the "standard operating procedure" at the Abu Ghraib prison will likely concern the American courts for years to come.

\section{Portfolio of Veterans}

A glance at Mike Leigh's remarkable award record shows that only the Berlinale was missing from his festival portfolio. That oversight was corrected when his sparkling comedy Happy-Go-Lucky (UK) was presented in Berlin. Sally Hawkins, as Poppy, an impish grammar-school teacher with a knack for upsetting her macho driving instructor and martinet dance teacher, was a runaway favourite from the outset to win the Silver Bear for Best Actress. The crowd in the Berlinale Palast roared its approval when the award was announced. Another festival veteran, Amos Kollek, returned to the Berlinale for the third time - after Sue (1997) and Bridgit (2002) - with Restless (Israel-Germany-Canada-Belgium-France), the story of a bittersweet father-son relationship between an unsettled New Yorker Jew and his abandoned Israeli son. To some degree, Restless reflects the director's relationship with his own father, Teddy Kollek (1911-2007), the popular mayor of Jerusalem. It received the Guild Award of German Art Houses.

Besides Mike Leigh and Amos Kollek, a dozen other veteran directors were warmly welcomed at the festival. Isabelle Coixet (My Life Without Me, 2002 Berlinale) returned with Elegy (USA) in the competition, about an upright professor (Ben Kingsley) led astray by a voluptuous student in his class (Penelope Cruz). Robert Guédiguian (Le promeneur du Champ de Mars, 2005 Berlinale, about the last days of French Premier François Mitterrand) resurfaced with Lady Jane (France), a film noir detective tale set in Marseilles among working-class friends. Michel Gondry (The Science of Sleep, 2006 Berlinale) returned with Be Kind Rewind (USA), an amusing out-of-competition closer that tips its hat to legendary jazz pianist Fats Waller.

After a 23-year absence, the popularity of Nanni Moretti was attested in Antonello Grimaldi's Caos calmo (Quiet Chaos, Italy). To some ext ent, the figure of Pietro in Quiet Chaos is a reprise of Moretti's own written-directed-acted La stanza del figlio (The Son's Room), the Golden Palm winner at the 2001 Cannes. Once again, we are asked to share a husband and father's grief, this time at the death of his wife. To con front the numbness in his soul, Pietro decides to hold a paternal vigil every day outside the school of his 10-year-old daughter. As senseless as this desperate move may sound, Nanni Moretti lends the tale an eccentric credibility.

\section{Grads and Debutantes}

Of the half-dozen entries by newcomers in the competition, only a few films were memorable as distinctive works of cinematic art and not just appropriate vehicles for the red-carpet parade. Justin Chadwick's The Other Boleyn Girl (UK-USA) pairs Natalie Portman and Scarlet Johanson as sisters in a gaudy Henry VIII costume drama. Dennis Lee's Fireflies in the Garden (USA) stars Julia Roberts and Willem Dafoe in a family drama of give-and-take grudges. Erick Zonca's Julia (France) features Tilda Swinton as a desperate middle-aged alcoholic in a rambling road movie thriller inspired by John Cassavetes's Gloria (1980).

On the other hand, Dieter Kosslick takes justified pride in furthering the careers of "graduates" from the Berlinale Talent Campus. Thus, Lance Hammer, who had participated in the 2004 Campus, was invited to compete this year with Ballast (USA), a tale of guilt shot in the Mississippi Delta with locals playing themselves. Also, Mexican director Fernando Eimbcke, a 2003 Campus participant, arrived at this year's competition as a proven international talent, whose first feature, Temporada de patos (Duck Season), had 
been a critical hit at the 2004 Cannes festival in the Week of the Critics section. A light comedy about a couple 14-year-old lads filling a boring weekend at home, Duck Season in turn paved the way for Lake Tahoe (Mexico) at this year's Berlinale. A minimalist comedy sprinkled with absurd twists, Lake Tahoe picks up where Duck Season left off, starring the same young actor (Diego Cataño, now a 16-year-old) as he wrestles with growing pains and family frustrations in a sleepy provincial Yucatan town. When he crashes the family car, he sets out to find an auto repair shop - and runs headlong into one absurd situation after another. Lake Tahoe was awarded the Alfred Bauer Prize by the International Jury and the International Critics FIPRESCI Prize.

Another newcomer in the Berlinale competition to keep an eye on, Philippe Claudel had already achieved fame as a writer before directing his first feature film, Il y a longtemps que je t'aime (I've Love You So Long, France-Germany). Set in Nancy, I've Love You So Long deals with past secrets and a fragile relationship between two sisters (Kristin Scott Thomas, Elsa Zylberstein). When the older sister (Thomas) arrives unexpectedly on the scene after having served a 15-year prison term, during which time all contact with her family had been broken off, her presence has to be accepted by the husband and two daughters as well. Tightly directed, with finely sketched performances, Philippe Claudel's Il y a longtemps que je t'aime received the Ecumenical Award and the Morgenpost Readers Award.

\section{Germany Omnipresent}

Upwards of 50 German entries are annually screened across the board at the Berlinale, including an increasing number of international co-productions. As a centrally located economic power on the European continent, Germany's omnipresence as a film production force is escalating year by year in accordance with the ever-expanding European Union. This said, it was not surprising to find that the two German films in the competition were distinctive for their cross-cultural characteristics. At first glance, Doris Dörrie's Kirschblüten - Hanami (Cherry Blossoms) appears to be as much Japanese as it is German, particularly as the key-noted second half of the film takes place in Tokyo and under Mount Fuji. Further, Dörrie's last two films - How to Cook Your Life, (2007), equating Zen Buddhism with cooking, and Der Fischer und seine Frau (The Fisherman and His Wife, 2005), inspired by a German folk tale shifted to a Japanese milieu are awash with unabashed infatuation for the land and its culture. Now comes Cherry Blossoms, with its unmistakable references to two Japanese classics: Ozu's Tokyo monogatari (Tokyo Story, 1953) in the first half, followed by Kurosawa's Ikiru (To Live, 1952) in the second. Add to this the metaphorical significance of white-body makeup in the Butoh dance and the fleeting impermanence of the cherry blossoms, and you enter the world of a puzzled provincial Bavarian trying to figure out why his late wife had been secretly enchanted by Japanese rituals. Before the film arrived at the Berlinale, Cherry Blossoms had received two Bavarian Film Prizes for Best Production and Best Actor (Elmar Wepper).

Luigi Falorni's Feuerherz (Heart of Fire, Germany-Austria) sparked controversy before the film had even premiered in the Berlinale competition. Set in war-torn Eritrea of 1981, Heart of Fire follows the destiny of a 10-year-old girl, a "child-soldier" taken by her father from an orphanage school run by Italian nuns to be recruited for the rebellion against Ethiopia. The controversy arose when the best-seller that had inspired the film - Senait Meharis's autobiography with the same title (published in 2004) - was challenged in the courts and reported in the press as drifting far from the truth. An Italian director, who had studied cinema at the Munich Film and Television School, Luigi Falorni is best known for his documentary, Die Geschichte vom weinenden Kamel (The Story of the Weeping Camel, 2003, Oscar Nomination 2005). Another film on the Competition dealing with child abduction, Damian Harris's Gardens of the Night (USA-UK), focused on the evil of child prostitution in the United States. Neither Heart of Fire nor Gardens of the Night fared well with critics and juries.

Thanks to production support lent by Fatih Akin, Özgür Yildirim, a fellow Turkish-German based in Hamburg, could write and direct Chiko, the story of a street drug-dealer who hopes to strike it rich by taking over a territory and running it with his friends in cahoots with a mafia boss. Inspired by Martin Scorsese Manhattan mafia films, particularly Good Fellas (USA, 1990), Özgür Yildirim stays close to the Turkish milieu he knows best. As Chiko (Denis Moschitto) muscles his way to the top to gain the confidence of Hamburg mafia boss Brownie (Moritz Bleibtreu), he gradually loses sight of his friends and pays the consequences. Programmed in the Panorama, Chiko scores as a gangster thriller narrated at a fast clip, although conspicuously absent of German cops, good or bad, to add a touch of credibility. 


\section{Absurdistan and Absurdities}

By far, the best German film at the Berlinale was Veit Helmer's delightful comedy Absurdistan. Awarded a Bavarian Film Prize, in addition to being critically acclaimed at Sundance, Absurdistan could only been seen in the European Film Market. Narrated with a minimum of dialogue in the vein of a Sergei Parajanov fairy tale, Absurdistan is set in a make-believe mountain village (apparently in Central Asia), where peaceful cohabitation between the sexes is equated with a life-giving underwater system. When the community's water supply suddenly dries up, inventive young Temelko (German actor Maximilian Mauff) struggles to stop the leak in the pipes before a long-awaited celestial alignment appears in the heavens. According to a fortune-teller, only an appropriate constellation of stars can guarantee Temelko the desired connubial bliss with his childhood girlfriend Aya (Czech actress Kristyna Malerová). With an armful of awards for two previous feature films - Tuvalu (1999) and Gate to Heaven (2003) - Veit Helmer ranks as the most provocative and promising filmmaker on the German scene today.

Don't miss Football Under Cover (Germany), a documentary by Ayat Najafi and David Assmann! Screened in the Perspektive Deutsches Kino section, the film takes the viewer to a Tehran stadium packed with thousands of cheering women. They are watching a friendly soccer match between the Iran national women's team and a thrown-together amateur team from Berlin-Kreuzberg. Because men are barred from the stadium, only camerawomen were present to chronicle the event, a rousing match that ended in a tie. As amusing as this sounds, the real story is what happened behind the scenes to enable the match to take place in the first place. One absurdity is piled upon another by Iranian authorities to sidetrack the event - until, finally, after a full year of negotiations, permission is finally given. Then, when the Kreuzberg girls arrive in Tehran, the last absurdity - an Iranian code of proper behaviour for women in a stadium - is thrown to the wind in the sheer joy of playing the game!

\section{German History Lessons}

Look in the Guinness Book of Records, and you will find that Barbara \& Winfried Junge's Die Kinder von Golzow (The Children of Golzow) scores as the longest running documentary portrait in the history of the cinema. The series began in a first-grade class in the rural village of Golzow (near the border to Poland) in August of 1961, immediately after the erection of the Berlin Wall had dramatically split Germany into two separate halves. When Karl Gass at the DEFA Documentary Studio approached Winfried Junge (later joined by editor Barbara Junge as co-director) with the idea for The Children of Golzow, his aim was to document the life-styles of a new generation of children educated in a socialist land. Later, however, the thematic focus shifted to the experiences of these young men and women after they had finished their schooling. Then, over the years, the Junge team followed them as they chose different professions, married and founded families, and consequently had to deal with the social changes brought about by German unification.

Thus, as a series that closely chronicled two great social and historical moments in East-West German history, Die Kinder von Golzow will increase in importance for years to come as a scholarly research source. Last year, when the first half of the closing documentary segment premiered at the 50th Leipzig DOKfestival under the title Und wenn sie nicht gestorben sind... Die Kinder von Golzow (And If they Haven't Passed Away... The Children of Golzow), it chronicled only the destinies of the last three remaining women in the class. This year, when the second half of the closing finale, ...dann leben sie immer noch (...Then They are Living Happily Ever After), was programmed in the International Forum of New Cinema at the Berlinale, it chronicled the lives of two remaining men in the class. Taken altogether, the documentation of all members of the original Children of Golzow class amounts to 2,570 minutes of viewing time, or nearly 43 running hours - a documentation covering 47 years of East-West German history. Indeed, a film of the century!

Gunther Scholz's Sag mir, wo die Schönen sind ... (The Beauties of Leipzig), programmed in the Panorama, chronicles the lives of nine wo=men. Today, they are all around forty. But back in 1989, when the film be gins, they were twenty and the German Democratic Republic (GDR) still existed. At that time, when they entered a contest for "Miss Leipzig," this publicized event in socialist East Germany was unusual, to say the least. Today, most of these women are married, some are still single, one is gett ing divorced; they have children, or are having a baby. One lives in Switz erland, another in Dubai, others in western Germany or still in Leipzig.

When the Leipziger Volkszeitung promoted the "Miss Leipzig 1989" beauty contest, Gerhard Gäbler, a student 
and amateur photographer, hit upon the idea of a photo-documentary project and asked the candidates if they would agreed to a sitting. Some contestants opted for a double-portrait - one at work, the other at home. Eighteen years later, when Gunther Scholz visited these women together with Gerhard Gäbler, they agreed to bring the stories of their lives up to the present. Today, their paths-of-life might seem puzzling or enigmatic, yet for their day their hopes for the future were rather typical. And that's what makes The Beauties of Leipzig a warmly human viewing experience - in addition to being an important social and historical document.

\section{East-West Turnstile}

There was a time when the Berlinale took pride in showcasing films from Eastern Europe. Here was a major international film festival serving as an East-West axis in the centre of Europe to facilitate communication and foster rapport among neighbouring countries. No more, it seems. This year, Hungary, one of the strongest filmlands in the CentEast region, was conspicuous for its absence. In fact, not a single entry from Central and Eastern Europe was programmed in the competition. And only one film from CentEast Europe was booked for the Berlinale Palast: Andrzej Wajda's Katyn (Poland), relegated to an out-of-competition slot.

To be sure, Katyn was an important film for both Poland and Germany, particularly in light of the fact that the massacre of 8,000 Polish officers in the Katyn Forest in March of 1940 had long been propagated by the Soviet Union as an act of German barbarity. Only after the fall of communism has it been proven otherwise. To find a way to shoot Katyn at all, Wajda drew upon dozens of letters, documents, and contemporary records to knit together a story of the massacre from separate yet interlinking accounts. Since one of them relates to the death of his own father among the slain officers, Katyn can be viewed as a personal requiem. Asked at the press conference about the film's nomination for an Oscar in the Best Foreign Language Film category, Andrzej Wajda responded: "My only wish at the moment is that Katyn be shown in Russia."

Some worthy entries from Central and Eastern Europe did find their way into the Berlinale sidebars. Anna Melikian's Rusalka (Mermaid, Russia), an adult fairy tale about an orphaned blithe spirit who can fulfill wishes, opened the Panorama and was awarded an International Critics (FIPRESCI) Prize. Pavel Koutecký and Miroslav Janek's Oban Havel (Citizen Havel, Czech Republic), an intimate, revealing, urbane documentary portrait of writer-playwright Václav Havel, who had served as the first President of the Czech Republic (1993-2003), belonged arguably in the Berlinale Palast instead of the International Forum of New Cinema. Boris Despodov's Corridor \#8 (Bulgaria), a documentary on the stumbling efforts of the European Union to build a modern highway on the traces of the ancient Via Egnatia (linking the Black and Adriatic Seas), comes across as absurdly funny when the populations of Greece, Bulgaria, Macedonia, and Albania were asked their opinions of why the "corridor" is running through their national living-rooms in the first place. Programmed in the Forum, Corridor \#8 was awarded an Ecumenical Prize.

\section{Far-East Pagoda}

Far-East cinema flooded the competition as though the Berlinale Palast had become a tiered pagoda of Asian dreams. But despite the presence of some name directors on the program, the echo in the press left the impression that Asian cinema may be losing some its luster on the world festival stage. China's Wang Xiaoshuai returned to the Berlinale (Silver Bear, Beijing Bicycle, 2001) with Zuo You (In Love We Trust) and was awarded a Silver Bear for Best Screenplay by the International Jury. In Love We Trust almost begs belief in this bleeding-heart tale of divorced parents faced with a life-saving decision. As implied in the original Chinese title, Left Right (meaning "conflicting perspectives"), the remarried parents (with other partners) find themselves in a dilemma when told by doctors that their leukaemia-stricken daughter can only be saved by a bone-marrow transplant. Since they themselves don't qualify as donors, the sole solution is to reunited for a time to have another child. With the credibility of the story on the line, Lan Weiwei, as the distraught mother, lends the film that needed measure of sympathy.

Japan's legendary 77-year-old director Yoji Yamada was another welcomed guest in the Berlinale competition. His Samurai films, in particular, have made him a festival favourite: Tasogare Seibei (The Twilight Samurai, 2002 Berlinale), Kakushi ken oni no tsume (The Hidden Blade, 2005 Berlinale), and Bushi no ichibun (Love and Honour, 2007 Berlinale). This time, in Kabei (Our Mother), he turned to Japanese pre-war history in the story of a conscientious writer and professor who was imprisoned in 1940 for "thought crimes" against 
the Imperial government. Based on a true-life biography, the afflicted yet resolute wife and mother, together with her two young daughters (one the biographer herself), must deal with the unknown fate of the husband and father as they go about their everyday lives. The presence of the woman's caring sister, her scolding father, and an admiring student of the professor add to the emotional exchange as events unfold towards the attack on Pearl Harbor and the news of the writer's death in prison. Although a melodrama anchored to a predictable outcome, Our Mother is memorable nonetheless for the poignant nuances in the acting performances.

Korea's Hong Sangsoo has carved out an atypical reputation as a cult director who deals in the banalities of the everyday. His films, charged with contradictions found in human relationships, seek resolutions in random or spontaneous conversations. After competing at Cannes with the enigmatic Yeojaneun namjaui miraeda (Woman Is the Future of Man, 2004) and Geuk jang jeon (Tale of Cinema, 2005), Hong presented his Haebyonui yoin (Woman on the Beach, 2006) at last year's Berlinale in the Panorama. This year, he returned to compete with Bam gua nat (Night and Day), set in Paris and running at a lengthy 145 min. Nothing much happens in Night and Day, save that the 40-year-old Kim Sung-nam (Kim Youngho), a successful painter, is on the run from a jail sentence in Korea for a minor derelict (drunk and smoking marijuana), misses his wife, and doesn't know exactly what he's doing in Paris. Chance meetings with fellow Koreans in this "city of love" lead to further complications until, in the end, his former life in Korea fades into the past.

Hongkong's Johnnie To, a regular visitor in the past to the International Forum of New Cinema, was invited this year to compete at the Berlinale with Man jeuk (Sparrow, Hongkong-China). Four years in the making, and often interrupted during shooting, Sparrow - a term for a pickpocket in Hongkong - forsakes the director's usual gun-and-gangster culture for a thriller set amid thieves and pickpockets on the streets of Hongkong. When a mysterious woman appears on the scene, who knows the secrets of the trade inside out, she enlists a gang of "sparrows" to settle a score with a tycoon boss. An spotty thriller at best, Sparrow was hardly competition caliber.

\section{Near East Neorealism}

One of the highlights of the competition came from Iran. Majid Majidi is best known for winning a bundle of prizes for Bacheha-Ye aseman (Children of Heaven), among them the Grand Prix des Amériques at the 1997 Montreal World Film Festival and the first-ever Oscar Nomination for an Iranian director. A neorealist tale about poor children secretly sharing the same pair of shoes on school days, Children of Heaven featured veteran actor Reza Najie in the role of the stern yet compassionate father faced with a meagre existence. Once again, in Avaze gonjeshk-ha (The Song of Sparrows), he plays a poor man struggling to support his family with the modest income earned by a motorbike taxi service. Down on his luck, he had lost his job at an ostrich farm when he let the bird run away! An actor with many talents to convey the desperate side of life, Reza Najie was awarded the Silver Bear for Best Actor.

Unfortunately overlooked for a slot in the Berlinale competition, Israeli director Eran Riklis's Lemon Tree(Israel-Germany-France) was programmed as a Panorama Special, was an immediate hit with critics, and was voted the First Prize by the Panorama audience. Following in the vein of his previous international hit, The Syrian Bride (2004), Lemon Tree features the same Israeli actress (Hiam Abbas) in a moving story that reduces the Israeli-Palestinian conflict to a comprehensive human dimension. The setting is a small Palestinian village on the West Bank, where a 45-year-old widow (Abbas) lives alone in a house surrounded by her lemon trees. When an Israeli minister builds a house across the way, he feels that the lemon trees are a security risk: they could hide terrorists and (even worse) might disturb the routine of his protective bodyguards. When he issues an order to have the trees must be cut down, the widow rebels - on the grounds that the lemon trees had been planted by her family generations ago. A court case ensues, one that escalates into myriad complications on the human scale. Lemon Tree deserves a long life on the festival circuit.

\section{Retrospective Tributes}

Not enough praise can be showered on Rainer Rother for organizing the all-embracing retrospective honouring the late great Luis Buñuel (1900-1983). Among the 32 films programmed in the retrospective were four separate screenings of his surrealist masterpiece, Un chien andalou (An Adalusian Dog, France, 1929), each with different contemporary musical accompaniment. A restored version of Jean Epstein's La chute de la 
maison Usher (The Fall of the House of Usher, France 1928), on which Buñuel worked as assistant director, could be seen with musical and acoustical accompaniment by a Dutch improvisational group. In an interview, published in the Die Zeit weekly to coincide with the retrospective, French actress Jeanne Moreau spoke with warm affection about the director, throwing light on the surreal concept behind the making of $L e$ journal d'une femme de chambre (Diary of a Chambermaid, France, 1964) in which she played the title role. According to Moreau, that singular adaptation of Octave Mirbeau's novel (published in 1900) offers arguably the most precise insights into the complexities of the Buñuel oeuvre.

Italian master Francesco Rosi (born 1922) was also honoured with a retrospective tribute. Billed as a "master of engaged cinema," Rosi was able to transport the principles of Italian Neorealism into the 1960s with some masterpieces that still deserve the attention of cineastes and the respect of historians. Noteworthy, too, was the Silver Bear for Best Director awarded to Francesco Rosi at the 1962 Berlinale for Salvatore Giuliano, a personal account of the life and death of the famous Sicilian bandit who was assassinated in 1950 and became a legend thereafter. In that acclaimed masterpiece, Rosi chronicled in some detail the separatist movement in Sicily following the Second World War, the subsequent communist peasant drive to challenge the Italian authorities, and then the link between a corrupt police and the mafia. Francesco Rosi received an Honorary Golden Bear at this year's Berlinale.

The International Forum of New Cinema also honoured 72-year-old Japanese director Koji Wakamatsu with a four-film retrospective tribute. The outstanding film in this series was Asama sanso e no michi (United Red Army), aka The Path to Asama Sanso, a 190-minute docu-drama about the postwar rise of the terrorist left in Japan. United Red Army begins in 1960, when militant students protested the renewal of the USJapanese Security Pact, and ends in 1972, when a small band of armed defenders withstood a 10-day siege at the Asama ski lodge, during which two policemen died. Along the way, and just prior to the siege of the ski lodge, 14 members of the group had fallen victim to the fanatical ideological dictates of two URA leaders. Since Koji Wakamatsu himself knew many of the student rebels personally, he lends a chilling authenticity to the events documented in the three-hour-plus report. United Red Army won the Netpac Award and the CICAE Art Cinemas Prize at the Berlinale. Don't miss it!

\section{References}

\section{AWARDS}

International Jury

Golden Bear

Tropa de elite (The Elite Squad, Brazil), dir José Padilha

Silver Bear, Grand Jury Prize

Standard Operating Procedure (USA), Errol Morris

Silver Bear, Best Director

Paul Thomas Anderson, There Will Be Blood (USA)

Silver Bear, Best Actress

Sally Hawkins, Happy-Go-Lucky (UK), dir Mike Leigh

Silver Bear, Best Actor

Reza Najie, Avaze gonjeshk-ha (Iran), dir Majid Majidi

Silver Bear, Outstanding Artistic Contribution (Music)

Jonny Greenwood, There Will Be Blood (USA), dir Paul Thomas Anderson

Silver Bear, Best Screenplay

Wang Xiaoshuai, Zuo You (In Love We Trust, China), dir Wang Xiaoshuai

Alfred Bauer Prize, Film of Particular Innovation

Lake Tahoe (Mexico), dir Fernando Eimbcke 
Best First Feature Award - Forum

Asyl - Park and Love Hotel (Japan), dir Kumasaka Izuru

Golden Bear, Short Film

O zi buna de plaja (A Good Day for a Swim, Romania), dir Bogdan Mustata

Silver Bear, Short Film - ex aequo

Udedh bun (Unravel, India), dir Siddharth Sinha

Prix UIP Berlin

Frankie(Ireland), dir Darren Thornton

DAAD Short Film Award

$V$ teme In the Theme, Russia), dir Olga Popova

Special Mentions

Superfície (Surface, Portugal), Rui Xavier

$R G B X Y Z$ (Ireland), David O'Reilly

Independent Juries

FIPRESCI (International Critics) Jury

Competition

Lake Tahoe(Mexico), dir Fernando Eimbcke

Panorama

Rusalka (Mermaid, Russia), dir Anna Melikian

Forum

Shahida (Shahida - Brides of Allah, Israel), dir Natalie Assouline

Ecumenical Jury

Competition

Il y a longtemps que je t'aime...(I've Loved You So Long..., France-Germany), dir Philippe Claudel

Special Mention

Zuo You (In Love We Trust, China), dir Wang Xiaoshuai

Panorama

Boy A(UK), dir John Crowley

Forum

Corridor \#8 (Bulgaria), dir Boris Despodov

Prize of Guild of German Art House Cinemas

Competition

Restless (Israel-Germany-Canada-Belgium-France), dir Amos Kollek

C.I.C.A.E. Jury (International Confederation of Art House Cinemas)

Panorama

Revanche (Revenge, Austria), dir Götz Spielmann

\section{Forum}

Asama sanso e no michi (United Red Army, Japan), dir Koji Wakamatsu

Label Europa Cinemas - Panorama

Revanche (Revenge, Austria), dir Götz Spielmann

Amnesty International Award - Panorama

Sleep Dealer (USA), dir Alex Rivera

Special Mention - Forum

Be Like Others (USA-Canada-Iran-UK), dir Tanaz Eshaghian 
Peace Film Award - Generation

Buda az sharm foru rikht (Buddha Collapsed Out of Shame, Iran-France), dir Hana Makhmalbaf

NETPAC (Network for Promotion of Asian Cinema) Prize - Forum

Asama sanso e no michi (United Red Army, Japan), dir Koji Wakamatsu

Special Mention

Paruthiveeran (India), dir Ameer Sulthan

Caligari Prize - Forum

Tirador (Slingshot, Philippines), dir Brillante Ma. Mendoza

Dialogue en Perspective Award - Perspektive Deutsches Kino

Drifter(Germany), dir Sebastian Heidinger

Special Mention

Lostage (Star-Crossed, Germany), dir Bettina Eberhard

Femina Film Prize - Panorama

Maria Gruber, Production Design

Revanche (Revenge, Austria), dir Götz Spielmann

Special Mention - Perspektive Deutsches Kino

Isabelle Baumgartner, Costume Design

Teenage Angst (Germany), dir Thomas Stuber

Panorama Awards

Manfred Salzgeber Award

Megane (Glasses, Japan), dir Naoko Ogigami

Special Mention

Improvvisamente l'inverno scorso(Suddenly, Last Winter, Italy), dir Gustav Hofer, Luca Ragazzi

Panorama Audience Award

First Prize

Lemon Tree (Israel-Germany-France), dir Eran Riklis

Second Prize

Darling! The Pieter-Dirk Uys Story(Australia), dir Julian Shaw

Third Prize

Erika Rabau - Puck of Berlin (Germany), dir Samson Vicent

Teddy Awards

Best Feature film - Panorama

The Amazing Truth about Queen Raquela (Iceland), dir Olaf de Fleur

Teddy Jury Prize - Forum

Be Like Others (USA-Canada-Iran-UK), dir Tanaz Eshaghian

Documentary - Perspektive Deutsches Kino

Football Under Cover (Germany), dir David Assmann, Ayat Najaf

Best Short Film - Panorama

Tá (Brazil), FelipeSholl

Generation Awards

Generation Kplus Jury

Crystal Bear, Best Feature Film

Buddha az sharm foru rikht (Buddha Collapsed Out Of Shame, Iran-France), dir Hana Makhmalbaf

Special Mention

Titanics ti liv (The Ten Lives of Titanic the Cat, Norway), dir Grethe Boe 
Crystal Bear, Best Short Film

Nana (Australia), dir Warwick Thornton

Special Mention

New Boy (Ireland), dir Steph Green.

Generation 14plus Jury

Crystal Bear, Best Feature Film

The Black Balloon (Australia), dir Elissa Down

Special Mention

Sita Sings the Blues (USA), dir Nina Paley

Crystal Bear, Best Short Film

Café com Leite (You, Me and Him, Brazil), dir Daniel Ribeiro

Special Mention

Take 3 (New Zealand), dir Roseanne Liang

Generation Kplus International Jury

Grand Prize, Best Feature Film

Tous à l'ouest! Une aventure de Lucky Luke (Go West! A Lucky Luke Adventure, France), dir Olivier Jean-Marie

Special Mention

Mutum (Brazil-France), dir Sandra Kogut

Special Prize, Best Short Film

Min morbror tyckte mychet om gult (My Uncle Loved the Colour Yellow, Sweden), dir Mats Olof Olsson

Special Mention

POST! (Germany), dir Christian Asmussen, Matthias Bruhn.

Tagesspiegel Readers Award - Forum

Liu lang shen gao ren (God Man Dog, Taiwan), dir Singing Chen

Berliner Morgenpost Readers Award - Competition

Il y a longtemps que je t'aime...(I've Loved You So Long..., France-Germany), dir Philippe Claudel

Siegessäule Readers Award - Panorama

Be Like Others (USA-Canada-Iran-UK), dir Tanaz Eshaghian

Volkswagen Audience Award - Perspektive Deutsches Kino

Football Under Cover (Germany), dir David Assmann, Ayat Najaf

Berlinale Talent Campus Awards

Volkswagen Score Competition

Conrad Oleak (Germany)

Berlin Today Award

Maheen Zia (Pakistan) for Match Factor

Honorary Golden Bear

Francesco Rosi

Berlinale Camera Awards

Karlheinz Böhm (Germany)

Otto Sander (Germany) 


\section{Author Information}

Ron HOLLOWAY (1933-2009) was an American critic, film historian, filmmaker and correspondent who adopted Europe as his home in the early fifties and spent much of his life in Berlin. He was an expert on the study of German cinema and against all odds produced, with his wife Dorothea, the journal German Film, keeping us up-to-date with the work of directors, producers and writers and the showing of German films around the world.

In 2007, Ron Holloway and his wife were awarded the Berlinale Camera Award. Ron also received the Bundesverdienstkreuz (German Cross of Merit), Polish Rings, Cannes Gold Medaille, the American Cinema Foundation Award, the Diploma for Support of Russian Cinema and an honorary award from the German Film Critics' Association.

Ron was also a valued contributor to Kinema for the past fifteen years. 